\title{
Microdialysis Fiber Electrodes for Glucose with Soluble and Immobilized Glucose Oxidase
}

\author{
Toshio YAo*†, Seita SuzukI*, Hirohito Nishino** and Taketoshi NAKAHARA* \\ *Department of Applied Chemistry, College of Engineering, and Department of \\ Advanced Materials Science, Research Institute for Advanced Science and \\ Technology, Osaka Prefecture University, Gakuencho, Sakai, Osaka 593, Japan \\ **Eicom Ltd., 24-2 Shimotobamendacho, Fushimi, Kyoto 612, Japan
}

Keywords Microdialysis fiber electrode, glucose sensor, poly(1,2-diaminobenzene) film, glucose oxidase, glucose, serum

\begin{abstract}
Microdialysis is a sampling technique for in vivo analysis. In many cases, the dialyzate collected by a microdialysis probe is assayed by $\mathrm{LC}^{1-4}$, but the time resolution of such an assay is not sufficient for real-time monitoring. Recently, a few attempts have been made to develop an on-line sensing system based on the use of a microdialysis probe in combination with an enzyme electrode ${ }^{5,6}$ or an immobilized enzyme reactor. ${ }^{7,8}$ Such a system makes possible on-line monitoring of metabolism in living tissue. These attempts are well suited for the assay of an analyte in the dialyzate with complex matrixes, because an enzyme can recognize specifically the analyte of interest in the dialyzate. However, such a flow system is not strictly a real-time monitoring process, because of the delay time between sampling and detection. In this research, we prepared a microdialysis enzyme electrode which makes possible real-time and in vivo monitoring. The electrode consists of a platinum fiber working electrode and a silver/silver chloride fiber reference electrode inserted into the tip and in the upper compartment of the dialysis fiber. We also selected glucose electrodes using glucose oxidase as a typical model of the sensor of this type. The measurements were first done by holding stationary a soluble enzyme solution in the probe cavity, and then by the electrode with enzyme layer immobilized on the platinum fiber working electrode. The response characteristics of both electrodes are evaluated below.
\end{abstract}

\section{Experimental}

\section{Reagents and solutions}

Distilled water purified with a Millipore Milli-Q system was used throughout. Glucose oxidase (242 U/ $\mathrm{mg}$ of protein, from Aspergillus niger, Type X-S) and

\footnotetext{
† To whom correspondence should be addressed.
}

bovine serum albumin (BSA, 96-99\% albumin) were from Sigma and were used as received. D-Glucose, glutaraldehyde ( $20 \%$ solution), sodium azide, uric acid, L-ascorbic acid, and 1,2-diaminobenzene were obtained from Wako. Control human sera were obtained from Wako and Ortho Diagnostic System. All other chemicals were of analytical reagent grade. All experiments were carried out in $\mathrm{pH} 5.5$ phosphate buffer containing $\mathrm{NaH}_{2} \mathrm{PO}_{4}(0.1 \mathrm{M}), \mathrm{NaCl}(0.15 \mathrm{M})$ and sodium azide $(1 \mathrm{mM})$. The buffer was balanced with $2 \mathrm{M} \mathrm{NaOH}$. All solutions were prepared with this buffer. Enzyme solutions were prepared by dissolving known weights of glucose oxidase in the same buffer solution $(200 \mu)$ ). Stock solutions used were $100 \mathrm{mM}$ glucose, $20 \mathrm{mM}$ urate, and $20 \mathrm{mM} \mathrm{L}$-ascorbate.

\section{Construction of microdialysis electrode}

Microdialysis electrode used in this work was of a design shown in Fig. 1, constructed by inserting a regenerated cellulose dialysis fiber (o.d. $220 \mu \mathrm{m}$, i.d. $200 \mu \mathrm{m}$; molecular cut-off approximately 50000) into a fused silica tube (o.d. $470 \mu \mathrm{m}$, i.d. $350 \mu \mathrm{m}$ ). The fiber was glued in the interior of the fused silica tube, leaving an active length of $5 \mathrm{~mm}$, and its end was sealed with epoxy cement. A more fine fused silica tube (as an inlet; o.d. $105 \mu \mathrm{m}$, i.d. $40 \mu \mathrm{m}$ ) and a poly(1,2-diaminobenzene) film-coated platinum fiber $(50 \mu \mathrm{m})$, which was prepared by the electropolymerization of 1,2-diaminobenzene according to the procedure described previously ${ }^{8}$, were inserted from the upper end of the probe as shown. In addition, another fine fused silica tube (as an outlet) and a silver/silver chloride ( $\mathrm{Ag} / \mathrm{AgCl})$ fiber $(50 \mu \mathrm{m})$ held into another dialysis fiber to prevent the electrical contact with the platinum fiber, were inserted from the upper end in a similar manner. The $\mathrm{Ag} / \mathrm{AgCl}$ fiber was prepared by electrolysis at $0.5 \mathrm{~V}$ vs. $\mathrm{Ag} / \mathrm{AgCl}$ in a saturated sodium chloride solution. The platinum fiber was used as a working electrode and the $\mathrm{Ag} / \mathrm{AgCl}$ fiber as a 


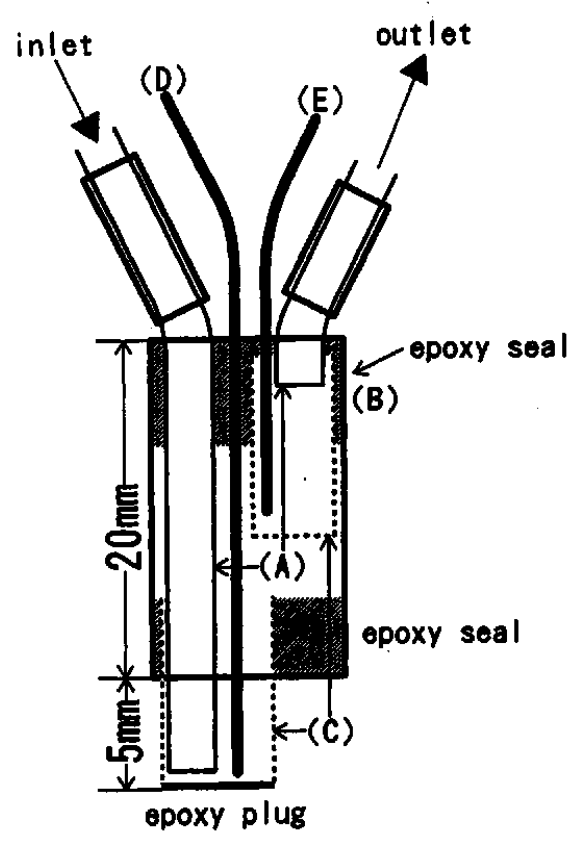

Fig. 1 Schematic diagram of microdialysis electrode: (A) fused silica tube (o.d. $105 \mu \mathrm{m}$, i.d. $40 \mu \mathrm{m}$ ); (B) fused silica tube (o.d. $440 \mu \mathrm{m}$, i.d. $350 \mu \mathrm{m}$ ); (C) dialysis fiber (o.d. $220 \mu \mathrm{m}$, i.d. $200 \mu \mathrm{m})$; (D) platinum fiber (50 $\mu \mathrm{m})$; (E) silver/ silver chloride fiber $(50 \mu \mathrm{m})$.

reference electrode. Two fine fused silica tubes were glued in the interior of the stainless-steel tubes (o.d. $440 \mu \mathrm{m}$, i.d. $220 \mu \mathrm{m}$ ) and the upper end of the probe was sealed completely with epoxy cement. All the parts used for the construction of the probes were gifts from Eicom.

Construction of ghucose microdialysis electrode and procedures Ghucose microdialysis electrode with soluble enzyme.

Prior to use, the microdialysis electrode was filled with the buffer by pumping with a microsyringe pump (Eicom EP-60). The enzyme solution was then infused into the electrode by the similar procedure. The internal enzyme solution was held in the microdialysis electrode throughout the experiment.

Glucose microdialysis electrode with immobilized enzyme.

Glucose electrode with immobilized enzyme was prepared by cross-linking glucose oxidase and BSA with glutaraldehyde on the poly(1,2-diaminobenzene) filmcoated platinum fiber. The method was as follows. Glucose oxidase $(240 \mathrm{U}), 10 \mu \mathrm{l}$ of $10 \%(\mathrm{w} / \mathrm{v})$ aqueous BSA, and $4 \mu \mathrm{l}$ of $4 \%(v / v)$ solution of glutaraldehyde were added to $25 \mu \mathrm{l}$ of $0.02 \mathrm{M}$ phosphate buffer (pH 5.5) and mixed well; this enzyme solution was used for the immobilization of enzyme. A poly(1,2-diaminobenzene) film-coated platinum fiber prepared previously was coated with the enzyme membrane, by soaking it in the enzyme solution and by drying for half a day at room temperature. This enzyme modified platinum fiber was used for the construction of glucose microdialysis electrode with immobilized enzyme.
The measurements were made by immersing the glucose fiber electrode in a measuring vial containing $2 \mathrm{ml}$ of the buffer with constant stirring. A constant potential of $+0.6 \mathrm{~V}$ was then applied to the fiber electrode by using a Yanagimoto VMD-101A potentiostat and the current was recorded by a Yanagimoto R3-201 recorder. When a steady baseline had been obtained, $500 \mu \mathrm{l}$ of the sample solution were added from a microsyringe. A steady-state response was obtained for the addition of the glucose solution.

\section{Results and Discussion}

\section{Glucose microdialysis electrode with soluble enzyme}

The dependence of the response on enzyme concentration was first determined. When the concentration of the glucose oxidase solution infused into the fiber electrode was increased from 10 to 1000 units, the response current to $5 \times 10^{-4} \mathrm{M}$ glucose was increased from 7 to $46 \mathrm{nA}$. However, the increase was only slight at higher enzyme concentrations, probably because the response was controlled by the rate of diffusion of glucose through the dialysis fiber. An enzyme concentration of $1000 \mathrm{U} / \mathrm{ml}$ was selected as the standard concentration for further experiments: On injection of $500 \mu \mathrm{l}$ of glucose solution into $2 \mathrm{ml}$ of $0.1 \mathrm{M}$ phosphate buffer (pH 5.5) containing $0.15 \mathrm{M} \mathrm{NaCl}$ and $1 \mathrm{mM}$ sodium azide, the current rapidly increased and a plateau corresponding to the steady-state response was reached within $10 \mathrm{~s}$. The current was proportional to the concentration of glucose. The calibration graph for glucose was linear from the detection limit $\left(5 \times 10^{-6} \mathrm{M}\right)$ to $1 \times 10^{-3}$ $\mathrm{M}$; the slope, the $y$ intercept, and the linear correlation coefficient were $92.5 \mathrm{nA} \mathrm{mM}^{-1}, 0.06 \mathrm{nA}$, and 0.998 . The relative standard deviation for seven replicate measurements was $2.6 \%$ for $5 \times 10^{-4} \mathrm{M}$ glucose.

This type of sensor has the advantages that the life time of the sensor can be extended by infusing in fresh enzyme solution when required and that a variety of sensors can be easily constructed by infusing the solution of the suitable hydrogen peroxide-producing enzymes without tedious immobilization procedures.

\section{Glucose microdialysis electrode with immobilized enzyme}

The $\mathrm{pH}$ dependence of the electrode response to $2 \times 10^{-4} \mathrm{M}$ glucose was examined over the $\mathrm{pH}$ range of 5.5-7.5. The maximum response was obtained at pH 6.5. Therefore, $0.1 \mathrm{M}$ phosphate buffer ( $\mathrm{pH}$ 6.5) containing $0.15 \mathrm{M} \mathrm{NaCl}$ and $1 \mathrm{mM}$ sodium azide was selected for subsequent work. The current was proportional to the concentration of glucose. The sensitivity to glucose was about $83 \%$ compared to that of glucose electrode with soluble enzyme. A linear calibration graph for glucose was obtained over $1 \times 10^{-6}-2 \times 10^{-3} \mathrm{M}$; the slope, the $y$ intercept and the linear correlation coefficient were $76.8 \mathrm{nA} \mathrm{mM}{ }^{-1}, 0.12 \mathrm{nA}$, and 0.998 . The limit of detection (signal-to-noise ratio=3) was $1 \times 10^{-6} \mathrm{M}$, because of low noise level owing to the 
Table 1 Analytical results for assays of glucose in human control serum

\begin{tabular}{|c|c|c|c|}
\hline \multirow[b]{2}{*}{ Control serum } & \multirow{2}{*}{$\begin{array}{l}\text { Indicated } \\
\text { value }^{\mathbf{a}} / \\
\mathrm{mg} \mathrm{dl}^{-1}\end{array}$} & \multicolumn{2}{|c|}{ Analyzed value $/ \mathrm{mg} \mathrm{dl}^{-1}$} \\
\hline & & $\begin{array}{c}\text { with } \\
\text { soluble } \\
\text { enzyme }^{c}\end{array}$ & $\begin{array}{c}\text { with } \\
\text { immobilized } \\
\text { enzyme }^{d}\end{array}$ \\
\hline Standard solution & 100 & $98.9 \pm 3.0$ & $99.2 \pm 2.3$ \\
\hline Wako I & $79 \pm 10$ & $81.8 \pm 2.8$ & $82.5 \pm 2.5$ \\
\hline Wako II & $255 \pm 14$ & $263.2 \pm 4.8$ & $260.8 \pm 4.4$ \\
\hline Ortho normal & $93 \pm 7$ & $90.9 \pm 2.8$ & $89.8 \pm 2.6$ \\
\hline Ortho abnormal & $296 \pm 23$ & $292.0 \pm 5.3$ & $288.2 \pm 4.9$ \\
\hline
\end{tabular}

a. Manufacturer's data.

b. Seven measurements on each sample.

c. Results obtained by microdialysis fiber electrode with soluble glucose oxidase $(1000 \mathrm{U} / \mathrm{ml})$.

d. Results obtained by microdialysis fiber electrode with immobilized glucose oxidase.

presence of enzyme membrane on the platinum fiber. However, the response time (about $50 \mathrm{~s}$ ) was somewhat slow compared to that for the soluble enzyme electrode, because of the additional diffusion through the enzyme membrane. This sensor could be repeatedly used for $20 \mathrm{~d}$.

\section{Glucose assay in human control sera}

Poly(1,2-diaminobenzene) film coated electrochemically on platinum fiber worked as a size-exclusion film as reported before ${ }^{9}$ and blocked completely the access of Lascorbate below $0.5 \mathrm{mM}$ in the dialyzate to the platinum fiber surface. Such a permselective characteristic of a poly(1,2-diaminobenzene) film was useful for the selective detection of low molecular weight hydrogen peroxide generated enzymatically for both sensors (with soluble and immobilized glucose oxidase).
Both sensors were used for the assay of glucose in human sera. The measurements were made by immersing each of the two sensors in a measuring vial containing $2 \mathrm{ml}$ of the buffer. After the constant baseline was obtained, $50 \mu \mathrm{l}$ of sera was added. The results are shown in Table 1, for both glucose fiber electrodes. Analytical results agreed closely with the manufacturer's data. The precision of the assay was almost the same for both electrodes; relative standard deviation for the repeat measurements $(n=7)$ was $1.7-3.4 \%$ for the assay of glucose in sera.

The present work was supported in part by a Grant-in-Aid for Scientific Research from the Ministry of Education, Science, Sports and Culture of Japan (No. 07640814).

\section{References}

1. W. H. Church and J. B. Justice, Jr., Anal. Chem., 59, 712 (1987).

2. C. E. Lunte, D. O. Scott and P. T. Kissinger, Anal. Chem., 63, 773A (1991).

3. B. H. C. Westerink, Tr. Anal. Chem., 11, 176 (1992).

4. M. T. Diaz, D. O. Scott and G. E. Lunte, Anal. Chem., 64, 806 (1992).

5. D. Moscone, M. Pasini and M. Mascini, Talanta, 39, 1039 (1992).

6. E. Zilkha, A. Koshy, T. P. Obrenovitch, H. P. Bennetto and L. Symon, Anal. Lett., 27, 453 (1994).

7. M. G. Boutelle, L. K. Fellows and C. Cook, Anal. Chem., 64, 1790 (1992).

8. T. Yao, S. Suzuki, H. Nishino and T. Nakahara, Electroanalysis, 7, 1114 (1995).

9. T. Yao, M. Satomura and T. Nakahara, Anal Chim. Acta, 296, 271 (1994).

(Received February 12, 1997)

(Accepted May 6, 1997) 